\title{
University Autonomy and Sustainable Finance: A Case of Royal University of Bhutan
}

\author{
Kriti Bhaswar Singh, Abhishek Singh
}

\begin{abstract}
Royal University of Bhutan was established in 2003 through Royal Charter. RUB is a decentralized university with eight colleges distributed across the country. In the year 2011, $R U B$ became fully autonomous university. After two years of successful autonomy, the $R U B$ was beginning to sense the gradual decline in government funding. This has put to test the future sustainability of the university. Colleges under RUB have saved the funds that was granted by the royal government of Bhutan (RGoB) to sustain in the future as there began gradual decline in grants during the coming years (Rigyal, 2013). This study is aimed to find the present investment policy of the colleges under RUB and recommend investment products for them to generate future sustainable income for the colleges \& university. In order to assess the knowledge of the investment, expected return \& risk and the preference of the colleges under RUB a set of questionnaire was administered. A total of 20 respondents, including President, finance personal and administrative officer, from 5 colleges (representing more than $60 \%$ of colleges) under RUB were taken for the study. Responses reveal the general investment policy of the colleges, present investment avenues adopted and return on them. All these facts were analyzed to propose portfolio for the colleges, which can help them to generate sustainable incomes.
\end{abstract}

Keywords:University autonomy, governance, Royal University of Bhutan, Sustainability.

\section{INTRODUCTION}

Royal University of Bhutan (RUB) was established in 2003 through Royal Charter, his Majesty the king Jigme Khesar Namgyal Wangchuck is the Chancellor of the RUB. RUB is a decentralized university with eight colleges under it spread across the country. All these colleges are autonomous. Out of eight we have taken five college for the present work. A brief profile of colleges is discussed in the following paragraphs.

Samtse College of Education (SCE) was founded as the first Teacher Training Institute in 1968 inaugurated by late third King, Jigme Dorji Wangchuck. It changed its name to Samtse College of Education in 2008. The college provides training to primary, secondary and postgraduate teachers in the country.

Paro College of Education (PCE) was established as a Pre-school care Training Centre in November 1975 located at Paro. PCE offers a wide range of programmes at the diploma, undergraduate and postgraduate levels for pre-service and in-service teacher candidate in the country.

College of Science and Technology offers (CST) undergraduate degree programmes in engineering. It was originally called Royal Bhutan Poytechnic (RBP) founded at Dewathang, Samdrup Jongkhar district in 1972 functioning with diploma in civil and electrical engineering. The institute was relocated to Rinchending, Phuentsholing under Chukha district with the command of the Fourth king Druk Gyalpo with an up gradation into an engineering college from polytechnic.

Gaeddu College of Business Studies (GCBS) offers business and management courses for undergraduates and masters level. The college started its operation in 2009 with the transfer of Department of Commerce from Sherubtse College. The college campus was developed by the Tala Hydroelectric Project Authority (THPA), located at Gedu, Chukha district.

College of Natural Resources (CNR) was started as the Natural Resources Training Institute (NRTI) in 1992 under the Ministry of Agriculture at Lobesa, Punakha district. The college joined the RUB in 2003 and changed its name to CNR offering diploma courses in the field of Agriculture, Animal Husbandry, and Forestry for the mid-level extension workers and the diploma courses are nested in its Bachelor program. It has started Masters Program recently.

In the year 2011, RUB became fully autonomous as a university. After two years of successful autonomy, RUB started to sensing gradual decline in government funding. This could put to test the future sustainability of the university. Colleges under RUB have saved the funds that were granted by the Royal government of Bhutan (RGoB) to sustain in the future, but as there began gradual decline in grants during the coming years these colleges need to explore new avenues to generate funds (Rigyal, 2013). One of the major issues of the colleges was concern regarding the budget. The colleges that have huge saved grants were facing ngultrum (Bhutanese local currency) liquidity hang-up, difficulty in finding suitable investment avenues in the country to generate returns on their monies. Investment in bank fixed deposit gave them very low return. Further, as per a top RMA (the central bank of Bhutan) official, banks are reluctant to accept huge deposit for the same reason of ngultrum liquidity hang up, that is the lack of investment 
avenues for themselves too (Business Bhutan, 2017). Thus, in this scenario colleges are facing two problems, one who have budget and funds and other who have unused funds. A suitable investment portfolio for the colleges can create sustainable incomes in future. Thereby colleges can focus more on developing their institutions into dynamic organization for learning and research.

\section{LITERATURE REVIEW}

Many authors support that universities endowment fund should not be kept idle rather should be invested to generate regular income, universities should develop a business model which will benefit them in return. An academic institution should explore all possible sources of funds; be it grant from the government, fees collection for the service provided or donations from its alumni. But institutions in a developing country like Bhutan, neither has strong alumni base contributing to college fund nor it can charge full fees for the educational services. Being granted autonomy requires institutions to become self-reliant in the resources. Samdrup Rigyal (2013), observed that the "RUB and all stakeholders (Colleges) might have to consider various options and will need to be creative, innovative and entrepreneurial in developing new sustainable business models suited to the future funding and market context". The University and the colleges have to be imaginative and work hard towards becoming self-reliant and sustainable institutions. All the colleges should have an understanding on the autonomy of the university and work towards looking beyond the boundary.

Merton (1993) states, "Institution with proper model of investment of their funds will be able to self-sustain and operate with any help of grants". Further, he observes that if institution keep on focusing more on spending the funds then investing in portfolio then in near future it will be difficult for any institution to survive. Little though has been devoted to the purpose for which endowments are maintained and that, as a consequence, their rate of accumulation and the pattern of spending from their income have been managed without much attention to the ultimate objectives of the institutions that hold them.

Further on having endowment funds, Hansmann (1990) addresses the question of why universities hold endowments rather than immediately spend all gifts. He concludes that universities should create endowment funds to ensure the survival of universities' reputational capital, protect intellectual freedom, and hedge against financial shock. Instead of spending all endowments fund and keeping the fund idle, why not they find some investment avenues whereby these funds will have stable return and lower risk. This will dissolve the problem of Ngultrum liquidity hang-up and can meet the necessities of the respective institution.

Hopkins and Massy (January, 1981) observes that there should be tradeoff between current spending of endowment yield and capital gain and the need for endowment growth that is needed to finance the day to day operation and to control the effects of inflation and provide for real budget enhancement in the future. Hansmann (1990) emphasis on university should see in what types of securities and other assets in which university endowment funds should be invested and, university should also set appropriate spending rule that is annual return on the endowment that should be spent for the university's current operations, rather than accumulated.

Brown Jr. (1999) states the performance of institutions of higher education is influenced by the sources of their revenue. Government funds to higher education are normally in the form of grants from government agencies. How this grant will to unutilized depend on individual and how they will sustain as government grant declined. Engberg \& Green, (2002) states "The most frequently cited reason for inaction in higher education is lack of funding". Financial constraints preclude faculty from participating in teaching, research and consulting projects from meaningful periods of time. Investing in faculty for research, project and other training actually will help ones' to self-sustain and retain one faculty in future.

Dimmock (August 2012) presents evidence that universities whose non-financial income (fees, grants, etc.) in more volatile invest more of their endowment fund in fixed income assets and reduce their allocation to risky assets. Gilbert et al., (2012) points out that university should invest funds in internal project, research, training to generate new university capital for a given positive internal investment.

James Fishman, (2014) observes organization with large endowments, such as colleges, universities, and private foundations, all finance a significant part of their operations through the return received from the investment of its capital. They must evaluate investing policies properly and do the necessary investment to survive in long-run. Claus and Thomas (2001) observed universities should adopt a business model that would streamline ones' approach to the classroom and to budgetary conundrums. Adopting business like models by universities could "generate ample funds to pay for ongoing construction of new facilities, expansion of the workforce and annual increases in staff compensation. Eshun Jr., (2009) notes "Researchers and practitioners share the consensus that the economic future of an organization depends on her ability to create and preserve wealth by continuously advancing creativity, fostering innovation, and promoting entrepreneurship,"

Gitman and Joehnk (2007), states that, investment is any vehicle into which funds can be placed with the expectation that will preserve or increase in value and generate positive returns. Investment is an outlay of a sum of money to be used in such a way that a profit or increase in capital may be expected (McCracken). Keynes refers 'investment as real investment and not financial investment'. The benefit from investment is called a return. Investors generally expect higher returns from riskier investments. Financial assets range from low-risk, low-return investments, such as high-grade government bonds, to those with higher risk and higher expected commensurate reward, such as equity investments. Investors often adopt an investment strategy 
and diversify their portfolio. Diversification has the statistical effect of reducing overall risk of a portfolio. Brown, et al (2010) defined asset allocation as the process of distributing investment capital across the various asset classes in an allowable universe. Asset allocation is considered to be one of the most important determinants of the portfolio's investment performance. With the detailed study on asset allocation investor can take a good decision on return and risk associate with the portfolio.

With the development of the private sectors in Bhutan, the market has opened new horizons for investment avenue and employment opportunities. To promote the private sector the government has divested the state-owned holdings in the profitable companies which contribute to the growth of capital market. Individuals, firms \& institutions can now invest in the capital market. Royal Securities Exchange of Bhutan (RSEBL) was established in 1993 as a non-profit making, quasi-public organization to tap and pool savings to finance the industries, which are in deficit; and also provides liquidity to the existing shareholders. So far till mid-2017, 21 companies are listed with RSEBL and 5 brokers licensed by the RMA. Introduction to stock market gives insight to the market as a fresher and the RSEBL information needed as to how, where and what to invest in.

Awalakki (2015) states investors are selecting different varieties of investment options for their investment with different objectives such as, profit, security, appreciation, income stability and appreciation. There are varieties of investment avenues available such as shares, bank, companies, real estate, life insurance, and postal savings and so on. All investors invest their surplus money based on their risk-taking attitude. A study of investment opportunities in Bhutan conducted by Department of Industry, MoEA in the year 2006 identified 10 prioritized projects for the private sectors to invest. The study provides with the inventory of country's resources such as infrastructure, tourism sector, services, trade and industry etc., as well as the investment opportunities in each Dzongkhag (Lit. - district in Bhutan) which may help in selecting avenues of investments (DoI, MoEA, 2006).

Review of literature shows that RUB and all colleges have to consider various investment options and will need to be creative in developing new sustainable business models suited to the future funding. Some institutions who have enough grant sitting idle in the bank account can too can explore suitable investment portfolio which can provide them with higher regular income. Most of the studies shown above are mainly done for developed market and there is a dearth of study done in developing market and none so far has been done in financial autonomy and creation of sustainable income in Bhutan.

\section{METHODOLOGY}

After RUB became autonomous in the year 2011, government grant to the university and its constituent colleges began to decline. Amid lower funding, the colleges have to explore methods to become self-sustainable. Some of the common ways colleges can generate sustainable income is by enrolling more self-financing students, finding suitable investment opportunities in market or investing in real estates. With this background the present work provides, in consultation with individual colleges and the university, a framework of investment of resources for short run and long run. It aims to inquire and find investment policy of the university and its constituent college. Further, it aims to create investment portfolio for the institutions under RUB which will optimize the returns for a given level of risk. Additionally, it will explore sources of sustainable revenue generation for the colleges.

The present work will be useful to RUB and its constituent colleges and explores various investment avenues available for them. It will evaluate and recommend suitable investment avenues for short as well as long term. With better use of funds colleges can generate higher revenue which can help in various purposes like retention of employee and improvement in the infrastructure of the institutions.

Data for the study was collected from both the primary and secondary source. In order to assess the knowledge of the investment, expected return \& risk and the preference of the colleges under RUB a set of questionnaire was administered. A total of 20 respondents, including president, finance personnel and administrative officer who have experience, expertise and were directly concerned with investment process of sampling colleges were selected. Five colleges, located in western region, under RUB were taken for the study. These colleges were: Gaeddu College of Business Studies (GCBS), College of Science and Technology (CST), Samtse College of Education (SCE), Paro College of Education (PCE), and College of Natural Resources (CNR).

Secondary data were respect to admission records, revenue and expenditure account were collected from the colleges websites, of the five colleges. Additionally, annual Reports of RUB for the last three years were obtained from the website of the university. Website of RSEBL, RMA, ministry of finance, banks etc. were searched for obtaining various investment options that are available in Bhutan.

There are various statistical tools used to analysis suitable investment avenues and create portfolio. Some of these tools that have been used in the study were mean, variance, standard deviation, compound annual growth rate, and covariance. Solver function in MS-Excel was used to create recommended portfolio.

\section{DATA ANALYSIS AND FINDINGS}

Analysis of responses obtained indicate that currently RUB has no investment policy framed for the colleges in the country. Further, there is no uniformity in the investment process among the colleges and colleges, being autonomous, invest their present funds only in the limited number of options available to them. These were bank fixed deposit and real estate.

Responses questionnaire reveals that 
most of the respondents had fair knowledge of investment options available in Bhutan (83\%). Very few (17\%) respondents said that they have very limited knowledge about investment products available. Every sample college had an investment committee where the college president, finance officer \& personnel, administrative officer and some faculty members were part of the committee. This committee decide investment plans of the college. Responses shows that this committee meets once in a year $(53 \%)$ and in some cases they meet more than twice a year $(24 \%)$.

Fixed deposits and investment in real estate were the major current investment by most of the colleges. $73 \%$ of the respondents indicated that the average return in the last three years was between $8 \%-10 \%$ and $27 \%$ respondents indicate the average returns between 5\%-8\%. Respondents were given a list of investment options, where more than one option could be chosen, to indicate their preferences. Responses indicate that most of them prefer bank fixed deposit (74\%), followed by investing in developing its human resource through training/workshops to its employees (32\%) and investment in bonds/debentures $(21 \%)$. Investment in real estate and shares were equally given preference of $16 \%$ each. Further $11 \%$ of the respondents have given their choice for investment in mutual fund, even though Bhutan has just one asset management company situated in Thimphu. Majority of the respondents $(67 \%)$ expected the rate of return from any future choice of investment option to generate up to $9 \%$ per annum, whereas remaining (33\%) expected it to be in the range of $9-15 \%$.

Responses for important factors in an investment shows that most of the respondents $(72 \%)$ indicated safety and liquidity from an investment followed by factors such as regular income $(14 \%)$, capital appreciation $(9 \%)$ and low risk $(5 \%)$. For the desired portfolio, $56 \%$ respondents agreed that the returns from portfolio to be for the self-sustainable funds for the college. Whereas, 33\% indicated that the portfolio should generate income at a later date and remaining (11\%) indicated for present income.

\section{ANALYSIS OF INCOMES AND EXPENDITURE STATEMENT OF COLLEGES}

Following table shows the total figures of incomes earned by colleges (in the form of government grants and fees) and expenditure obtained from the Income \& Expenditure statement reported by the colleges during the Financial Year 2015-2018.

Table- I: Income and Expenditure of Five colleges (FY-2015-2018)

\begin{tabular}{|l|c|c|c|}
\hline College Name & Total Income (Nu.) & Total Expenditure (Nu.) & $\begin{array}{c}\text { Excess } \\
\text { Income/Expenditure } \\
\text { (Nu.) }\end{array}$ \\
\hline \multicolumn{4}{|c|}{ Samtse College of Education } \\
\hline FY-2015-2018 & $205,626,914.23$ & $198,186,447.13$ & $7,440,467.1$ \\
\hline \multicolumn{5}{|c|}{ Paro College of Education } \\
\hline FY-2015-2018 & $434,972,863.96$ & $272,051,101.89$ & $162,921,762.07$ \\
\hline \multicolumn{5}{|c|}{ College of Science and Technology } \\
\hline FY-2015-2018 & $242,087,596.55$ & $265,457,361.62$ & $(23,369,765.06)$ \\
\hline \multicolumn{5}{|c|}{ Gaeddu College of Business } \\
\hline FY-2015-2018 & $321,852,400.17$ & $342,795,543.93$ & $(20,943,143.76)$ \\
\hline \multicolumn{5}{|c|}{ College of Natural Resources } \\
\hline FY-2015-2018 & $292,667,276.39$ & $336,651,249.61$ & $(43,983,973.22)$ \\
\hline
\end{tabular}




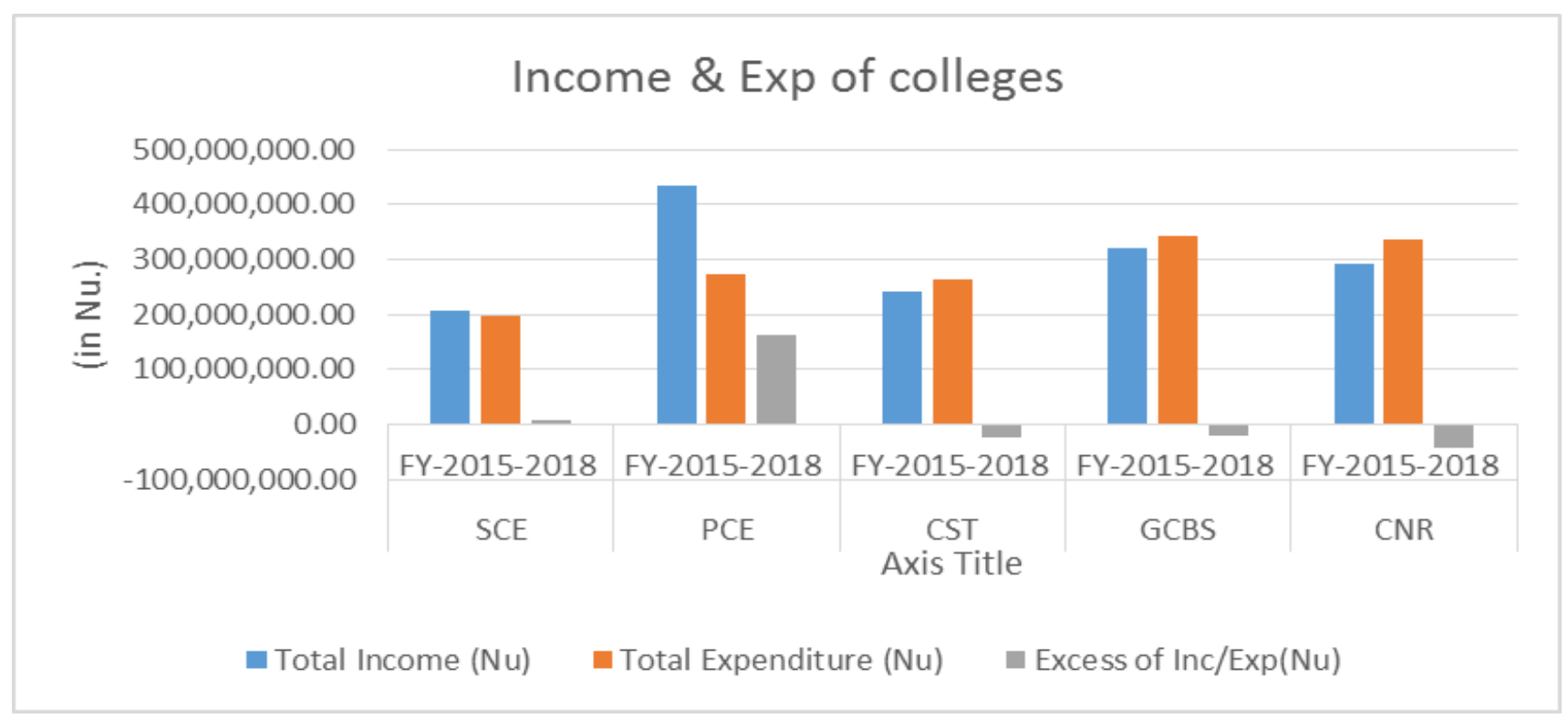

Figure1: Graph representing the income and expenditure of respective colleges

The above graph depicts the total income and expenditure of the colleges during the financial year 2015-2018. The colleges like SCE and PCE have surplus funds in their account. However, colleges like CST, GCBS and CNR have deficits. PCE and SCE colleges should look for other investment avenues than bank deposit for sustainable income for them, when government grant declines in future.

\section{RECOMMENDATIONS}

After analyzing the revenue and expenditure statements, it was observed that all the colleges depend on RGoB grants and these forms the major source of income for the colleges. Analyzing the number of student, we found that each college has two types of students on their roll; one who receives RGoB grants and the other who are self-financing student for each course that the college offer. Therefore, it is suggested that the colleges should, in the scenario of declining grants, increase the proportion of self-financing students. Following tables shows the worked out effect on total fees through increasing self-financing students.

A) Samtse College of Education (SCE)

Table II: Scholarship and Self-financed students of SCE

\begin{tabular}{|c|l|c|c|c|c|c|c|}
\hline \multicolumn{9}{|c|}{ Govt. Scholarship \& Self Finance } \\
\hline $\begin{array}{c}\text { Sl. } \\
\text { No }\end{array}$ & \multicolumn{1}{|c|}{ FY } & $\begin{array}{c}\text { Govt. } \\
\text { Scholarship }\end{array}$ & $\begin{array}{c}\text { RGoB grant } \\
\text { (Nu. in M) }\end{array}$ & $\begin{array}{c}\text { Self-Finan } \\
\text { ce Student }\end{array}$ & $\begin{array}{c}\text { SF Fee } \\
\text { (Nu. in M) }\end{array}$ & $\begin{array}{l}\text { Total } \\
\text { Stds. }\end{array}$ & Total fees \\
\hline 2 & $2015-2016$ (Actual Values) & 840 & 53.22 & 74 & 4.51 & 914 & 57.73 \\
\hline 3 & $2016-2017$ (Actual Values) & 633 & 60.45 & 144 & 5.44 & 777 & 65.89 \\
\hline 4 & $2017-2018$ (Actual Values) & 547 & 64.66 & 172 & 9.48 & 719 & 74.14 \\
\hline 5 & $\begin{array}{l}\text { 2018-2019 (Projected } \\
\text { Values) }\end{array}$ & 500 & 70.38 & 218 & 11.18 & 718 & 81.56 \\
\hline 6 & $\begin{array}{l}\text { 2020-2021 (Projected } \\
\text { Values) }\end{array}$ & 500 & 76.1 & 277 & 14.20 & 777 & 90.30 \\
\hline 7 & $\begin{array}{l}2022-2023 \text { (Projected } \\
\text { Values) }\end{array}$ & 500 & 81.82 & 342 & 17.54 & 842 & 99.36 \\
\hline
\end{tabular}

SCE have been decreasing the number of government scholarship every year, and increasing the number of selffinance student in the year 2015 to 2018 as per our observation. We suggest SCE to fix the number of student for government scholarship to 500 or decrease as the year goes by and increase the number of self-financing students annually by $25 \%$. With the increase in the self-financed students every year, the college will earn the more revenue to sustain college. 
Table III: Scholarship and Self-financed students of PCE

\begin{tabular}{|c|c|c|c|c|c|c|c|}
\hline \multicolumn{8}{|c|}{ Govt. Scholarship \& Self Finance } \\
\hline $\begin{array}{l}\text { Sl. } \\
\text { No }\end{array}$ & FY & $\begin{array}{c}\text { Govt. } \\
\text { Scholarship }\end{array}$ & $\begin{array}{l}\text { RGoB grant } \\
(\text { Nu. in } M)\end{array}$ & $\begin{array}{c}\text { Self-Finance } \\
\text { Student }\end{array}$ & $\begin{array}{c}\text { SF Fee } \\
(\mathrm{Nu} . \text { in } \mathrm{M})\end{array}$ & $\begin{array}{l}\text { Total } \\
\text { Stds. }\end{array}$ & $\begin{array}{c}\text { Total } \\
\text { fees }\end{array}$ \\
\hline 1 & 2015-2016 (Actual Values) & 948 & 69.49 & 99 & 6.30 & 1,047 & 75.79 \\
\hline 2 & 2016-2017 (Actual Values) & 968 & 79.31 & 111 & 8.67 & 1,079 & 87.98 \\
\hline 3 & 2017-2018 (Actual Values) & 906 & 74.56 & 122 & 8.57 & 1,028 & 83.13 \\
\hline 4 & $\begin{array}{l}2018-2019 \text { (Projected } \\
\text { Values) }\end{array}$ & 850 & 77.1 & 133 & 9.40 & 983 & 86.50 \\
\hline 5 & $\begin{array}{l}2020-2021 \text { (Projected } \\
\text { Values) }\end{array}$ & 850 & 79.64 & 153 & 10.81 & 1,003 & 90.45 \\
\hline 6 & $\begin{array}{l}\text { 2022-2023 (Projected } \\
\text { Values) }\end{array}$ & 850 & 82.18 & 164 & 11.59 & 1,014 & 93.77 \\
\hline
\end{tabular}

Similarly, PCE shows the decline of number of students through RGoB grants and increase in the self-financing students in the year 2015 to 2018 respectively. The increase in the number of self-finance students in PCE can be by $15 \%-20 \%$ yearly and in doing that PCE can generate sum of
Nu.9.4 million; Nu.10,81 million; Nu.11.59 million in the year 2019, 2020 and 2021 respectively. Increasing the self-finance students number will help PCE to generate revenue without any risk and will be able to sustain when government decline annually.

C) College of Natural Resources (CNR)

Table IV: Scholarship and Self-financed students of CNR

\begin{tabular}{|c|l|c|c|c|c|c|c|}
\hline \multicolumn{2}{|c|}{ Govt. Scholarship \& Self Finance } \\
\hline $\begin{array}{c}\text { SI. } \\
\text { No }\end{array}$ & $\begin{array}{c}\text { FY } \\
\text { Gcholarsh } \\
\text { ip }\end{array}$ & $\begin{array}{c}\text { RGoB } \\
\text { grant } \\
\text { Nu. in } \\
\text { M) }\end{array}$ & $\begin{array}{l}\text { Self-Finan } \\
\text { ce Student }\end{array}$ & $\begin{array}{c}\text { SF Fee } \\
\text { (Nu. in } \\
\text { M) }\end{array}$ & $\begin{array}{l}\text { Total } \\
\text { Stds. }\end{array}$ & Total fees \\
\hline 1 & $\begin{array}{l}\text { 2015-2016 (Actual } \\
\text { Values) }\end{array}$ & 376 & 37.48 & 38 & 3.22 & 414 & 40.7 \\
\hline 2 & $\begin{array}{l}\text { 2016-2017 (Actual } \\
\text { Values) }\end{array}$ & 487 & 48.54 & 50 & 4.23 & 537 & 52.77 \\
\hline 3 & $\begin{array}{l}2017-2018 \text { (Actual } \\
\text { Values) }\end{array}$ & 510 & 50.83 & 81 & 6.86 & 591 & 57.69 \\
\hline 4 & $\begin{array}{l}2018-2019 \text { (Projected } \\
\text { Values) }\end{array}$ & 500 & 57.51 & 102 & 8.64 & 602 & 66.15 \\
\hline 5 & $\begin{array}{l}2020-2021 \text { (Projected } \\
\text { Values) }\end{array}$ & 500 & 64.19 & 128 & 10.84 & 628 & 75.03 \\
\hline 6 & $\begin{array}{l}\text { 2022-2023 (Projected } \\
\text { Values) }\end{array}$ & 500 & 70.87 & 163 & 13.80 & 663 & 84.67 \\
\hline
\end{tabular}

CNR shows increase in the number of government scholarship students as well as increase in the number of self-finance students from 2015 to 2018 . We suggest CNR to limit the number of government scholarship to 500 or decrease the numbers every year, and increase the self-financing students by $25 \%$ to $30 \%$ annually, which will increase revenue. $\mathrm{CNR}$, thus will generate sum of $\mathrm{Nu} .8 .64$ million in the year 2019, Nu.10.84 million in the year 2020 and Nu.13.80 million in the year 2021 from self-finance students as depicted in the above table. 
D) College of Science and Technology (CST)

Table V: Scholarship and Self-financed students of CST

\begin{tabular}{|c|c|c|c|c|c|c|c|}
\hline \multicolumn{8}{|c|}{ Govt. Scholarship \& Self Finance } \\
\hline $\begin{array}{l}\text { Sl. } \\
\text { No }\end{array}$ & $\mathbf{F Y}$ & $\begin{array}{c}\text { Govt. } \\
\text { Scholars } \\
\text { hip }\end{array}$ & $\begin{array}{c}\text { RGoB } \\
\text { grant }(\mathrm{Nu} . \\
\text { in } \mathrm{M})\end{array}$ & $\begin{array}{l}\text { Self-Finance } \\
\text { Student }\end{array}$ & $\begin{array}{c}\text { SF Fee } \\
(\mathrm{Nu} \text {. in M) }\end{array}$ & Total Stds. & Total fees \\
\hline 1 & $\begin{array}{l}\text { 2015-2016 (Actual } \\
\text { Values) }\end{array}$ & 636 & 58.64 & 45 & 4.15 & 681 & 62.79 \\
\hline 2 & $\begin{array}{l}\text { 2016-2017 (Actual } \\
\text { Values) }\end{array}$ & 684 & 63.03 & 107 & 9.87 & 791 & 72.90 \\
\hline 3 & $\begin{array}{l}2017-2018 \text { (Actual } \\
\text { Values) }\end{array}$ & 704 & 70.17 & 151 & 15.05 & 855 & 85.22 \\
\hline 4 & $\begin{array}{l}\text { 2018-2019 (Projected } \\
\text { Values) }\end{array}$ & 700 & 75.97 & 205 & 19.42 & 905 & 95.39 \\
\hline 5 & $\begin{array}{l}\text { 2020-2021 (Projected } \\
\text { Values) }\end{array}$ & 700 & 81.77 & 277 & 26.23 & 977 & 108.00 \\
\hline 6 & $\begin{array}{l}\text { 2022-2023 (Projected } \\
\text { Values) }\end{array}$ & 700 & 87.57 & 356 & 33.72 & 1056 & 121.29 \\
\hline
\end{tabular}

CST should limit the number of students to 700 or decrease the numbers and increase the self-financing students number to by $35 \%$. Fee of CST, compared to other colleges, is high, as it is an engineering college. Increase in number self-financing students can easily resolve the acute shortage of money in college and don't have to depend much on government grants.

E) Gaeddu College of Business Studies (GCBS)

Table VI: Scholarship and Self-financed students of GCBS

\begin{tabular}{|c|c|c|c|c|c|c|c|}
\hline \multicolumn{8}{|c|}{ Govt. Scholarship \& Self Finance } \\
\hline $\begin{array}{l}\text { Sl. } \\
\text { No }\end{array}$ & FY & $\begin{array}{c}\text { Govt. } \\
\text { Scholarship }\end{array}$ & $\begin{array}{c}\text { RGoB } \\
\text { grant }(\mathrm{Nu} . \\
\text { in } \mathrm{M})\end{array}$ & $\begin{array}{c}\text { Self-Financ } \\
\text { e Student }\end{array}$ & $\begin{array}{c}\text { SF Fee } \\
(\mathrm{Nu} . \text { in } \mathrm{M})\end{array}$ & Total Stds. & Total fees \\
\hline 1 & $\begin{array}{l}\text { 2015-2016 (Actual } \\
\text { Values) }\end{array}$ & 895 & 78.02 & 333 & 10.74 & 1,228 & 88.76 \\
\hline 2 & $\begin{array}{l}\text { 2016-2017 (Actual } \\
\text { Values) }\end{array}$ & 898 & 90.05 & 434 & 11.42 & 1,332 & 101.47 \\
\hline 3 & $\begin{array}{l}\text { 2017-2018 (Actual } \\
\text { Values) }\end{array}$ & 885 & 87.08 & 564 & 16.94 & 1,449 & 104.02 \\
\hline 4 & $\begin{array}{l}\text { 2018-2019 (Projected } \\
\text { Values) }\end{array}$ & 700 & 91.61 & 679 & 20.03 & 1,379 & 111.64 \\
\hline 5 & $\begin{array}{l}\text { 2020-2021 (Projected } \\
\text { Values) }\end{array}$ & 700 & 96.14 & 819 & 24.15 & 1,519 & 120.29 \\
\hline 6 & $\begin{array}{l}\text { 2022-2023 (Projected } \\
\text { Values) }\end{array}$ & 700 & 100.67 & 958 & 28.25 & 1,658 & 128.92 \\
\hline
\end{tabular}

As shown in the above table 6 there is a decline trend on the government scholarship students, and increase in the number of self-finance students from 2015 to 2018 as per our observation. We suggest GCBS to limit the number of government scholarship to 700 or reduce the number each year, and increase the number of self-finance students by $15 \%$ to $20 \%$.

Most of the colleges have unused land around the college built up area. Therefore, development of real estate for commercial purpose is advised. This is also indicated as one of the preferred investment choice by the respondents. Rental income from these properties is expected to generate sustainable income for the colleges in long-term. Ministry of finance website (www.mof.bt) indicates the following house rent deduction rates, this can be used to measure the expected returns from the rental property: 
Table VII: House rent deduction category-wise

\begin{tabular}{|c|c|c|}
\hline Sl. No. & Category & $\begin{array}{c}\text { Revised house rent Nu. per sq. } \\
\text { ft (from 1st October 2016) }\end{array}$ \\
\hline 1 & Town A & $\mathrm{Nu} .4,659$ \\
\hline 2 & Town B & $\mathrm{Nu} .3,666$ \\
\hline 3 & Town C & $\mathrm{Nu} .3,328$ \\
\hline 4 & Town D & $\mathrm{Nu} .2,995$ \\
\hline 5 & Rural area with motor able road access & $\mathrm{Nu} .2,662$ \\
\hline 6 & Rural area with no motor able road access & $\mathrm{Nu} .1,331$ \\
\hline
\end{tabular}

\section{CONCLUSION}

The study concludes that the colleges after granted autonomy should explore the avenues of investment for creating sustainable incomes amid declining government grants. Most of the respondents from the colleges have been investing in fixed deposit of banks and have shown preferences for other choices available in the market. Bhutan has a very limited choice of investment product and therefore colleges can choose among real estate investment, bonds, and government securities. Additionally, college need to increase the number of self-financing students to increase income.

\section{REFERENCES}

1. Awalakki, M. S. (2015). A Study on Investment Patterns and Awareness of Salaried Class Investors. International Journal of Scientific Research (IJSR), 4(8), 348-350.

2. Bahl, S. (2012). The Role of Green Banking in Sustainable Growth International Journal of Marketing, Financial Services \& Management Research, 2(2), 27-35.

3. Black, F. (1976). The Investment Policy Spectrum: Individuals, Endowment Funds and Pension Funds. Charlottesville: CFA Institute.

4. BNBL. (2017). Bhutan National Bank Ltd. Retrieved October 2017 , from http://www.bnb.bt

5. Boyer, E. (1990). Scholarship reconsidered. Princeton, NJ: Carnegie Foundation.

6. BusinessBhutan. (2017, February). Business Bhutan. Retrieved from businessbhutan

http://businessbhutan.bt/bhutans-liquidity-hang-up/

7. David Engberg, M. F. (2002). Promising Practices: Spotlighting Excellence in Comprehensive Internationalization. Washington, DC. American Council on Education.

8. David S. P. Hopkins, W. F. (January, 1981). Planning Models for Colleges and Universities. California: Stanford University Press.

9. Dimmock, S. G. (August 2012). Background Risk and University Endowment Funds. The Review of Economics and Stastistics, 94(3), 789-799. Retrieved from http://hdl.handle.net/10220/12203

10. DoI, MoEA. (2006). Investment Opportunity Study. Thimphu: Author.

11. Dresner, S. (2003). PIPE: A Guide to Private Investments in Public Equity. Bloomberg Press.

12. Fabozzi, F. J. (1999). Investment Management. New Jersey: Prentince Hall, Inc.

13. Fishman, J. (2014). What Went Wrong: Prudent Management of Endowment Funds and Imprudent Endowment Investing Policies. Journal of College and University Law, 40(2), 49.

14. Frank Reilly, K. B. (2002). Investment Analysis \& Portfolio Management. Mason, OH: South-Western Cengage Learning.

15. Hansmann, H. (1990). Why Do Universities Have Endowments? The Journal of Legal Studies, 3-42.

16. Iyiola Omisore, M. Y. (March 2012). The modern portfolio theory as an investment decision tool. Journal of Accounting and Taxation, 4(2) 19-28.

17. Jones, C. P. (2007). Investment Analysis and Management. New Delhi: Wiley India Pvt. Ltd.

18. Jr., J. P. (2009). Business incubation as strategy. Business Strategy Series, 10(3), 156-166.

19. Jr., W. O. (1999). Sources of Funds and Quality Effects in Higher Education. ECONSTOR Make Your Publication Visible, 35.

20. Keith C. Brown, L. G. (2010). Asset allocation and portfolio performance: Evidence from University endowments funds. Journal of Financial Markets, 268-294.

21. Lawrence J. Gitman, M. D. (2007). Planning Your Personal Finances Massachusetts, US: Cengage Learning.

22. Mark A. Youndt, M. S. (March 2004). Intellectual Capital Profiles: An Examination of Investments and Returns*. Journal of Management Studies, 335-361.

23. Maxwell, T. W. (2012). Academic Work in an Autonomous Royal University of Bhutan: Challenges and Responsibilities Regarding Research. Bhutan Journal of Research \& Development, 37-49.

24. Merton, R. C. (1993). Optimal Investment Strategies for University Endowments Funds. In M. R. Charles T. Clotfelter, Studies of Supply and Demand in Higher Education (pp. 211-242). Chicago: University of Chicago Press.

25. N. Walia, R. K. (2009). An Analysis of Investor's Risk Perception towards Mutual Funds Services. International Journal of business Management, 4(5), 106-120.

26. PCAL. (2017). Penden Cement Authority Ltd. Retrieved February 25, 2017, from http://www.pcal.bt

27. Rigyal, D. S. (2013). University autonomy and sustainability: Faculty perceptions on the sustained growth of the Royal niversity of Bhutan. Bhutan Journal of Research \& Development, 17-29.

28. RMA. (2014-2015). Annual Report. Thimphu: Author.

29. RMA. (2015-16). Annual Report. Thimphu

30. RMA. (2016). Monetary Policy Statement. Thimphu

31. RMA. (2017, February). Royal Monetary Authority of Bhutan. Retrieved from https://www.rma.org.bt/db_noticetp.jsp

32. RSEBL. (2009). Introducing the Stock Market. Thimphu

33. RSEBL. (August 2009). Introducing the Stock Market. Thimphu

34. RUB. (2011). Research Guidelines. Retrieved 2017, from Royal University of Bhutan: http://www.rub.edu.bt/index.php/research-guidelines

35. RUB. (2014). Annual Report. Thimphu

36. Soderbaum, J. (2017). Research and development - government, business and universities. Retrieved February 20, 2017, from ACIL ALLEN Consulting: http://www.acilallen.com.au/sector/3/research-and-development-govern ment-business-and-universities

37. Thomas Gilbert, S. K. (2012). Investor inattention and the market impact of summary statistics. Management Science, Special Issue on Behavioral Economucs and Finance, 58, 336-350.

38. Thomas, J. C. (2001). Equity premium as low as 3 percent? Evidence from analysts earnings forecasts for domestic and international stock markets. Journal of Finance, 1629-1666.

39. Todor Stoilov, V. I. (2003). Portfolio Optimization of Investment Decisions on the Securities Market in Bulgaria. Bulgaria: CompSystech.

40. Wilcox, J. W. (1999). Investing By The Numbers. USA: Frank J Fabozzi Associates.

Zvi Bodie, A. K. (1999). The Investment Environment. In A. K. Zvi Bodie, Investments (p. 3). US: Irwin/McGraw-Hill. 